\title{
Pola Spasial Kekeringan di Jawa Barat Pada Kondisi El Nino Berbasis Metode Palmer Drought Severity Index (PDSI)
}

\author{
Spatial Drought Pattern In West Java under El Nino Condition Based on \\ Palmer Drought Severity Index (PDSI) Method
}

\author{
Ika Purnamasari $\left.{ }^{1 *}\right)$, Tri Wahyu Saputra ${ }^{1}$, Suci Ristiyana ${ }^{1}$ \\ ${ }^{1}$ Program Studi Agroteknologi, Fakultas Pertanian, Universitas Jember. Jalan Kalimantan N0 37, Krajan \\ Timur, Sumbersari, Kabupaten Jember Regency, Jawa Timur 68121
}

\author{
Article info: \\ Kata kunci: \\ CRU, El Niño, Jawa Barat, pola spasial \\ kekeringan, PDSI \\ Keywords: \\ CRU, El Niño, PDSI, spatial drought \\ pattern, West Java
}

Article history:

Received: $16-12-2020$

Accepted: 18-03-2021

${ }^{*}$ Koresponden email:

ikapurnamasari@unej.ac.id

\begin{abstract}
Abstrak
Permasalahan hidrometeorologi berupa kekeringan menjadi tantangan yang dihadapi Indonesia, khususnya Jawa Barat. Terjadinya kekeringan di Jawa Barat yang beriklim muson erat kaitannya dengan fenomena El Niño Southern Oscillation (ENSO). Salah satu metode untuk mengukur tingkat kekeringan adalah dengan metode Palmer Drought Severity Index (PDSI). Penelitian ini bertujuan untuk menentukan tingkat kekeringan di wilayah Jawa Barat berdasarkan metode PDSI pada kondisi normal dan El Niño serta membuat peta sebaran tingkat kekeringan. Data curah hujan dari Climate Research Unit (CRU) 2000-2012 digunakan dalam studi ini. Pola spasial penghitungan PDSI kemudian dipetakan berdasarkan musim. Model spasial kekeringan berdasarkan indeks Palmer menunjukkan bahwa puncak kekeringan terjadi pada bulan Juni-Juli-Agustus (JJA) dan September-Oktober-November (SON). Kekeringan merata di seluruh Jawa Barat pada periode Juli hingga Agustus yang berpusat di Jawa Barat bagian utara dari September hingga November. Pada periode Januari hingga Maret, kekeringan hanya terkonsentrasi di sebagian kecil wilayah Jawa Barat bagian barat dan selatan. Peristiwa El Niño pada musim kemarau (JuniNovember) meningkatkan parahnya kekeringan di Jawa Barat.
\end{abstract}

\begin{abstract}
The hydrometeorological problem in the form of drought is a challenge facing Indonesia, especially West Java. The occurrence of drought in West Java, which has a monsoon climate, is closely related to the El Niño Southern Oscillation (ENSO) phenomenon. One method for quantifying the level of drought is Palmer Drought Severity Index (PDSI) method. This study aims to determine the drought level in the West Java region based on the PDSI method under normal and El Niño conditions and mapped the spatial pattern of PDSI. Rainfall data from the Climate Research Unit (CRU) 20002012 was used in this study. The spatial pattern of PDSI calculations then mapped based on seasonality. The spatial drought model based on the Palmer index shows that the peak of drought occurs in JuneJuli-August (JJA) and September-October-November (SON). The drought is evenly distributed throughout West Java in the July to August period that centered in northern West Java from September to November. In the January to March period, the drought only concentrated in a small part of the western and southern parts of West Java. El Niño events during the dry season (June-November) increase the severity of drought in West Java.
\end{abstract}

Kutipan: Purnamasari,I., Saputra T.W.,, Ristiyana, Pola Spasial Kekeringan di Jawa Barat Pada Kondisi El Nino Berbasis Metode Palmer Drought Severity Index (PDSI), Jurnal Teknik Pengairan. https://doi.org/10.21776/ub.pengairan.2021.012.01.02 


\section{Pendahuluan}

Kekeringan adalah kondisi kekurangan air di bawah normal baik berupa kekurangan curah hujan, kelengasan tanah, air bumi dan debit sungai (Tallaksen et al., 2009). Kekeringan merupakan bencana yang meluas di dunia dengan ciri khas frekuensi tinggi, cakupan luas durasi lama serta memiliki pengaruh yang parah (Wang et al., 2018). Kejadian iklim ekstrim yang menimbulkan bencana hidrometeorologi seperti banjir dan kekeringan di wilayah Indonesia dipengaruhi oleh kejadian ENSO (El Niño Southern Oscillation) (Surmaini \& Faqih, 2016).

Wilayah Indonesia yang beriklim monsun merupakan wilayah yang terkena dampak ENSO terbesar. Hal ini karena wilayah tersebut berkaitan dengan sirkulasi angin antara belahan bumi Utara (Asia) dan belahan bumi Selatan (Australia). Haefele et al. (2016) menyatakan bahwa Kejadian El Niño dan La Niña berdampak pada peningkatan luas lahan pertanian yang mengalami bencana kekeringan dan kekeringan. Hal ini mengakibatkan puso sehingga menurunnya produksi pangan. Gangguan ENSO di Pulau Jawa merupakan yang terbesar, karena Pulau Jawa merupakan pusat wilayah monsunal Asia-Australia. Dampak El Niño maupun La Niña secara signifikan terlihat pada September hingga November. Fenomena El Niño juga memberikan dampak signifikan dalam menurunkan curah hujan di Pulau Jawa pada Desember dan Januari (Qian et al., 2010).

Wilayah Jawa Barat merupakan salah satu wilayah di Pulau Jawa yang sering mengalami kekeringan saat fenomena El Niño. Sementara itu, Jawa Barat adalah produsen padi terbesar di Indonesia dengan rata-rata produksi $17 \%$ dari produksi nasional selama periode tahun 2010-2014 (Badan Pusat Statistik, 2020). Peristiwa El Niño kuat telah mengakibatkan penurunan produksi, sementara kejadi-an La Niña berdampak kepada peningkatan produksi padi (Mulyaqin 2020). Penurunan serupa juga diamati di Maluku dengan penurunan produksi sebesar 2,9\% dari produksi padi ekpektasi (Santoso, 2016). Gangguan kekeringan dapat menyebabkan aktivitas dan produksi pertanian terganggu. Dampak negatif kekeringan dapat diminimalisir dengan mengenali karakteristik pola kekeringan. Karakteristik kekeringan merupakan analisis sifat-sifat hujan yang dapat menggambarkan kondisi kekeringan menggunakan indeks kekeringan.

Salah satu metode untuk mengkuantifikasi tingkat kekeringan adalah metode Palmer atau lebih dikenal dengan Palmer Drought Severity Index (PDSI). Metode PDSI menggunakan prinsip neraca air dalam menilai kekeringan dengan mengukur kondisi kelengasan tanah yang telah distandarisasi sehingga dapat diperbandingkan secara spasial dan temporal (Mavi \& Tupper, 2004). Penelitian ini bertujuan untuk menentukan tingkat kekeringan di wilayah Jawa Barat berdasarkan metode PDSI pada kondisi normal dan El Niño serta membuat pemetaan sebaran tingkat kekeringan di wilayah Jawa Barat.

\section{Bahan dan Metode}

\subsection{Alat dan Bahan}

Penelitian ini menggunakan Personal Computer yang dilengkapi perangkat lunak ArcMap GIS 10.2 serta Grid Analysis and Display System (GrADS) versi 2.0.a9.oga.1. Bahan penelitian dan sumber data wilayah Jawa Barat disajikan pada Tabel 1 sebagai berikut :

Tabel 1. Bahan Penelitian

\begin{tabular}{llll}
\hline No & Jenis Data & Periode & Sumber \\
\hline 1 & $\begin{array}{l}\text { Data curah hujan bulanan Climate } \\
\text { Research Unit (CRU) Jawa Barat }\end{array}$ & 2000-2012 & http://badc.nerc.ac.uk/ \\
\hline 2 & $\begin{array}{l}\text { Data suhu rata-rata bulanan Climate } \\
\text { Research Unit (CRU) Jawa Barat }\end{array}$ & ho00-2012 & http://badc.nerc.ac.uk/ \\
\hline 3 & $\begin{array}{l}\text { Peta dan data jenis tanah wilayah } \\
\text { Jawa Barat }\end{array}$ & $\begin{array}{l}\text { Balai Besar Sumberdaya Lahan } \\
\text { Pertanian (BBSDPL) }\end{array}$ \\
\hline 4 & $\begin{array}{l}\text { Peta dan data tata guna lahan wilayah } \\
\text { Jawa Barat }\end{array}$ & Badan Informasi Geospasial (BIG) \\
\hline 5 & Data Digital Elevation Model (DEM) & $\begin{array}{l}\text { https://asterweb.jpl.nasa.gov/gdem.asp } \\
\text { dan https://glovis.usgs.gov/. }\end{array}$ \\
\hline
\end{tabular}




\subsection{Tahapan Penelitian}

Tahapan penelitian yang dilakukan mengikuti diagram alir pada Gambar 1. Data input yang digunakan meliputi data suhu, curah hujan, peta jenis tanah dan peta tutupan lahan. Peta jenis tanah dan tutupan lahan digunakan untuk menduga kapasitas air tersedia dan perhitungan neraca air. Koefisien parameter iklim yang selanjutnya digunakan untuk penentuan indeks Palmer ditentukan berdasarkan nilai evaporanspirasi potensial, curah hujan serta neraca air. Nilai indeks Palmer selanjutnya dipetakan secara spasial.

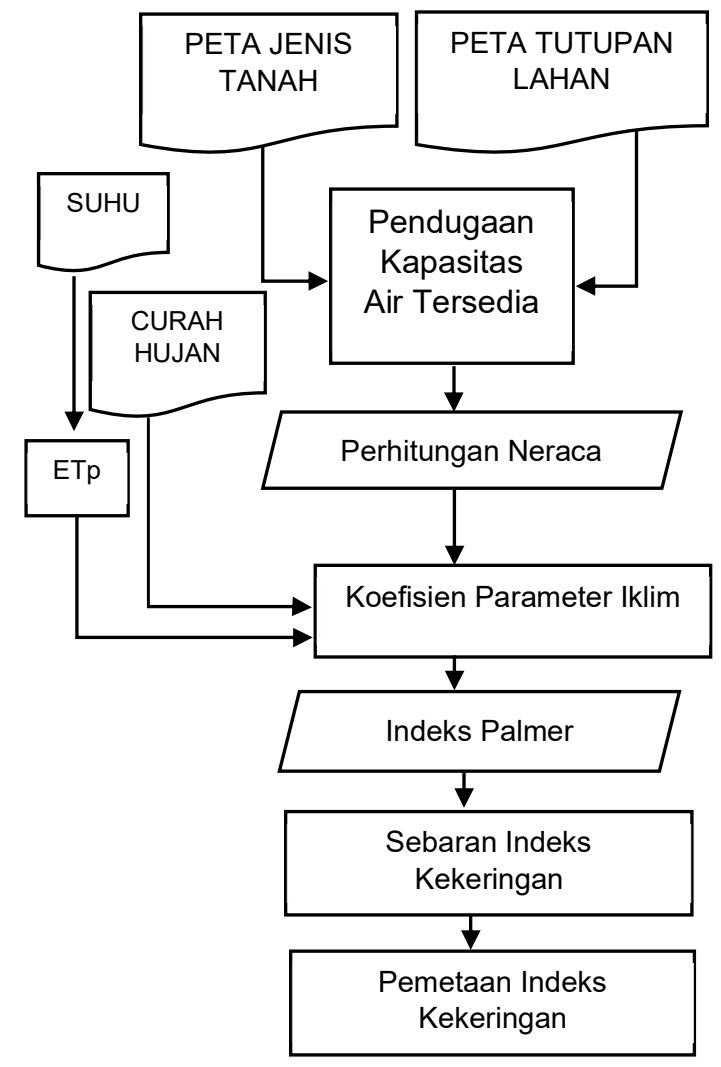

Gambar 1. Diagram Alir Penelitian

\subsection{Pembagian Wilayah Penelitian}

Wilayah penelitian seperti pada Gambar 2 dibagi menjadi 21 wilayah berdasarkan resolasi spasial $\left(0.5 \times 0.5^{\circ}\right)$ data suhu dan curah hujan Climate Research Unit. (Mitchell \& Jones, 2005).

\subsection{Perhitungan Kapasitas Air Tersedia (KAT)}

Tahapan awal dari pendugaan KAT adalah melakukan tumpang susun peta jenis tanah dan peta penggunaan lahan sehingga diperoleh luas jenis tanah dan penggunaan lahan pada setiap wilayah tersebut. Selanjutnya adalah mmebagi lapisan tanah menjadi dua lapisan yaitu lapisan atas dengan kedalaman $\pm 25 \mathrm{~cm}$ dan lapisan tanah bagian bawah dengan kedalaman sesuai zona perakaran. Nilai KAT setiap jenis tanah didapatkan dari table pendugaan Thornthwaite dan Mather (1957). Metode Thornwaite dan Mather (1957) digunakan secara standar dalam perhitungan neraca air oleh United States Geological Survey (USGS 2021). Nilai KAT (mm) untuk setiap lapisan tanah dihitung dengan Persamaan 1 berikut ini:

Keterangan:

$$
K A T_{1}=L x K A T_{j} x T_{1}
$$

$$
\begin{array}{cll}
K A T_{1} & =\text { Kapasitas air tersedia tiap lapisan (mm) } \\
L & =\text { Presentase luas penggunaan lahan }(\%)
\end{array}
$$




$$
\begin{array}{rll}
K A T_{j} & =\text { Kapasitas air tersedia pada tiap jenis tanah }(\mathrm{mm} / \mathrm{m}) \\
T_{1} & =\text { Tebal lapisan tanah }(\mathrm{m})
\end{array}
$$

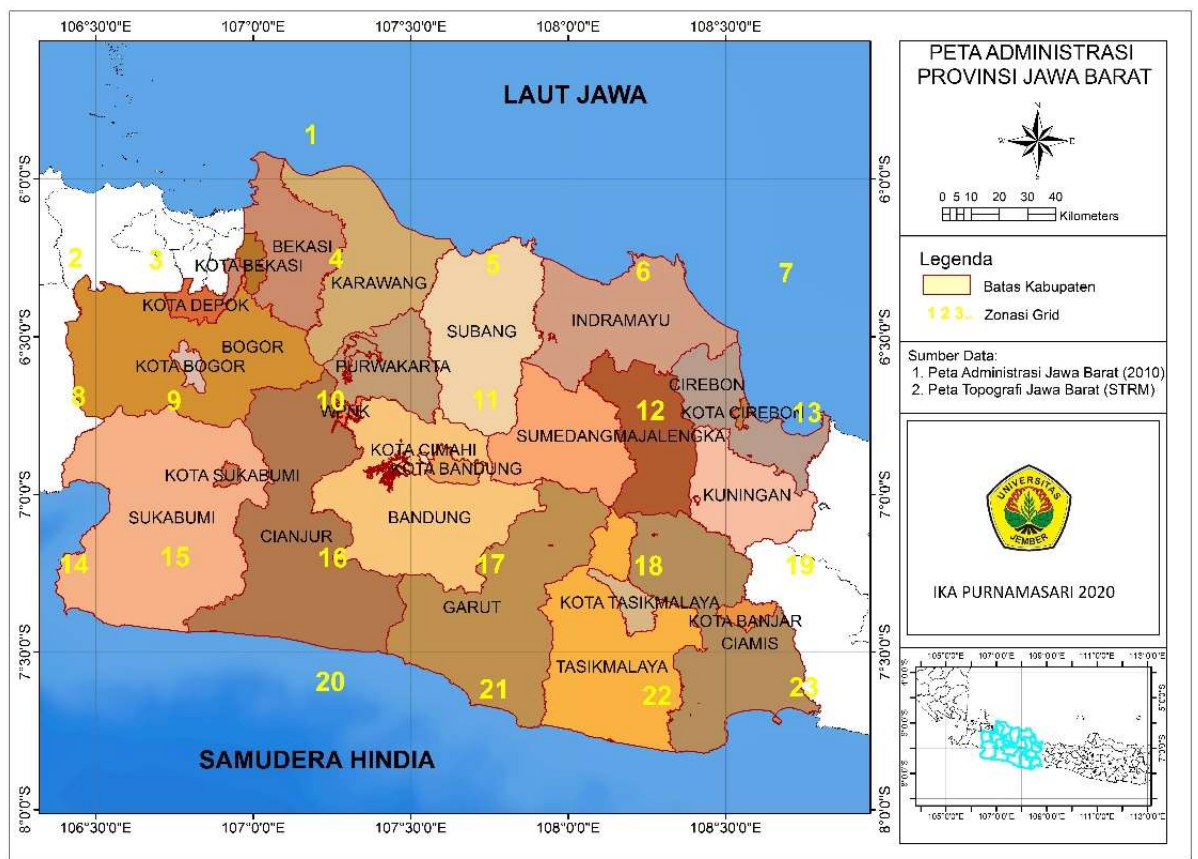

Gambar 2. Pembagian grid berdasarkan data curah hujan dan suhu udara CRU

\subsection{Perhitungan Evapotranspirasi Potensial (ETp)}

Evapotranspirasi potensial setiap wilayah diduga dengan menggunakan metode Thornthwaite mengikuti Persamaan 2 sampai Persamaan 5. Data suhu rata-rata bulanan yang dipergunakan berasal dari Climate Research Unit (CRU). Data CRU ini merupakan data bulanan hasil observasi berbasis grid beresolusi tinggi dengan ukuran $0.5 \times 0.5 \mathrm{~km}$. Data CRU pertama kali dikeluarkan pada tahun 2000 menggunakan ADW (Angular Distance Weighting) untuk menginterpolasi data observasi bulanan hingga resolusi spasial $0.5 \times 0.5 \mathrm{~km}$ (Harris et al., 2020).

$$
\begin{aligned}
& E T p *=E T p x f \\
& E T p=16\left(\frac{10 T}{I}\right)^{a} \\
& I=\sum_{i j} \\
& f=\frac{D}{30}
\end{aligned}
$$

Keterangan :

$$
\begin{aligned}
& \mathrm{ETp}=\text { Evapotranspirasi terkoreksi (mm) } \\
& \mathrm{T}=\text { Suhu rata-rata bulanan }\left({ }^{\circ} \mathrm{C}\right) \\
& A=6.75 \times 10^{-7} \mathrm{I}^{3}-7.710^{-5} \mathrm{I}^{2}+1.792 \times 10^{-2} \mathrm{I}+0.49239 \\
& D=\text { Panjang hari berdasarkan lintang (jam) } \\
& i=\left(\frac{T}{5}\right)^{1.514}
\end{aligned}
$$

\subsection{Perhitugan Neraca Air dan Indeks Kekeringan}

Terdapat asumsi dalam perhitungan neraca air, asumsi pertama yaitu lengas tanah pada lapisan atas tidak akan masuk ke bawah sebelum jenuh. Asumsi kedua, lengas pada lapisan bawah tidak akan keluar apabila lengas pada lapisan tersebut belum habis. Selain itu, diperhitungkan pula kehilangan air (loss), masukan air (recharge), evapotranspirasi aktual, dan limpasan permukaan (runoff). Asumsi ketiga, limpasan permukaan akan terjadi ketika kedua lapisan tanah telah mencapai 
kapasitas lapang. Perhitungan neraca air digunakan untuk menghitung konstanta-konstanta yang mendefinisikan karakteristik iklim sebagai berikut : koefisien evepotranspirasi $(\alpha)$, koefisien recharge $(\beta)$, koefisien runoff $(\gamma)$, koefisien loss $(\delta)$, pendekatan pertama terhadap faktor pembobot $(\mathrm{K})$.

Faktor pembobot K pada metode Palmer memungkinkan untuk menstandarkan ketersediaan air dari iklim rata-rata sehingga nilai kekeringan dapat diperbandingkan secara spasial dan temporal (Guttman et al., 1992). Sebagai contoh, nilai -2 di wilayah A akan memiliki arti yang sama di wilayah lainnya, meskipun memiliki jarak yang jauh dan waktu yang berbeda.

Dilakukan analisis klimatologi jangka panjang untuk menurunkan kelima konstanta, yang selanjutnya akan mendefinisikan kondisi iklim. Nilai konstanta Koefisien tersebut memungkinkan untuk menghitung presipitasi yang telah terjadi selama bulan tertentu, yang dipertimbangkan sebagai kondisi normal yang mengacu pada ketersediaan air. Besarnya evapotranspirasi pada bulan tersebut dapat dihitung dengan menggunakan Persamaan 6. P adalah presipitasi dugaan, ETp merupakan evapotranspirasi potensial sedangkan PR, PRO dan PL menggambarkan Potential recharge, Potential runoff dan Potential loss.

$$
\mathrm{P}=\alpha \mathrm{ETp}+\beta \mathrm{PR}+\gamma \mathrm{PRO}+\delta \mathrm{PL}
$$

Berdasarkan persamaan 6, nilai curah hujan dipengaruhi oleh kondisi cadangan air dalam tanah serta nilai evapotranspirasi bulan sebelumnya. Selisih antara curah hujan pengamatan dan curah hujan dugaan dinotasikan dengan huruf $d$. Huruf $Z$ pada persamaan 7 merupakan nilai indeks anomali lengas merupakan perkalian selisih hujan dengan faktor pembobot $\mathrm{K}$. Indeks kekeringan akhir (X) bergantung pada nilai $\mathrm{Z}$ yang didapatkan dengan Persamaan 7 dan Persamaan 8.

$$
\begin{aligned}
& x=\left(\frac{Z}{3}\right)_{j-1}-\Delta X \\
& \text { dengan } \Delta X=\left(\frac{Z}{3}\right)_{j}-0.103\left(\frac{Z}{3}\right)_{j-1}
\end{aligned}
$$

Tingkat keparahan dalam satu bulan dinotasikan dengan $\mathrm{Z} / 3$, sedangkan notasi $-0.103(\mathrm{Z} / 3)_{\mathrm{j}-1}$ adalah nilai tingkat keparahan. Konstanta 0,103 diperoleh dari penurunan persamaan jumlah kekeringan abnormal. Konstanta ini diperlukan untuk melihat tingkat keparahan kekeringan yang selanjutnya menentukan tingkat perubahan keparahan kekeringan sebagai nilai indeks kekeringan (Palmer, 1965). Nilai indeks positif menunjukkan tidak terjadi kekeringan (basah) sedangkan saat indeks menunjukkan nilai negatif menunjukkan terjadi kekeringan. Klasifikasi Indeks Palmer dinyatakan pada Tabel 2. Menurut Guttman et al (1992), indeks kekeringan Palmer sangat efektif untuk menentukan kekeringan jangka panjang serta daerah beriklim tropis.

Tabel 2. Klasifikasi Indeks Palmer

\begin{tabular}{cc}
\hline Indeks Kekeringan & Sifat Cuaca \\
\hline$>4.00$ & Ekstrem Basah \\
\hline $3.00-3.99$ & Sangat Basah \\
\hline $2.00-2.99$ & Agak Basah \\
\hline $1.00-1.99$ & Sedikit Basah \\
\hline $0.50-0.99$ & Awal Selang Basah \\
\hline $0.49-(-0.99)$ & Normal \\
\hline$-0.5-(-0.99)$ & Awal Selang Kering \\
\hline$-1.00-(-1.99)$ & Sedikit Kering \\
\hline$-2.00-(-2.99)$ & Agak Kering \\
\hline$-3.00-(-3.99)$ & Sangat Kering \\
\hline$<-4.00$ & Ekstrim Kering \\
\hline
\end{tabular}




\subsection{Pemetaan Sebaran Kekeringan Berdasarkan Metode Palmer}

Hasil indeks kekeringan setiap grid $\left(0.5^{\circ} \times 0.5^{\circ}\right)$ dipetakan secara spasial menggunakan ArcGIS 10.2. Selanjutnya tingkat kekeringan dipisahkan saat kondisi El Niño, La Niña dan Normal.

\section{Hasil dan Pembahasan}

\subsection{Karakteristik Wilayah Jawa Barat}

Secara astronomis, wilayah Jawa Barat berada pada koordinat $5^{\circ} 50^{\prime}-7^{\circ} 50^{\prime}$ Lintang Selatan (LS) dan $104^{\circ} 48^{\prime}-108^{\circ} 48^{\prime}$ Bujur Timur (BT). Wilayah Jawa Barat memiliki luas daratan 3.735.327 hektar. Berdasarkan kelerengannya, daratan Jawa Barat dibedakan menjadi tiga kelas yaitu: 1) pegunungan curam dengan ketinggian lebih dari 1.500 meter di atas permukaan laut (dpl). Kelas ini mendominasi wilayah bagian selatan (Grid 14-17 dan 20-23 pada Gambar 2) dengan luas 9.5\% dari luas total wilayah Jawa Barat; 2) wilayah lereng berbukit yang landai $(10-1.500 \mathrm{~m} \mathrm{dpl})$ yang mendominasi Jawa Barat bagian tengah (Grid 8-12 dan 18-19) dengan luas 36.48\%; dan 3) wilayah dataran rendah $(0-10 \mathrm{~m} \mathrm{dpl})$ dengan luas $54.03 \%$ terletak di Jawa Barat bagian utara (Grid 1-7 dan 13) (BIG 2010).

Tutupan lahan Jawa Barat sebanyak $35.9 \%$ berupa persawahan, $12 \%$ berupa ladang dan perkebunan, sebanyak $26.9 \%$ berupa hutan primer dan sekunder, sebanyak $11.3 \%$ berupa lahan terbangun dan industri sedangkan sisanya berupa semak belukar dan badan air. Tanah Latosol mendominasi wilayah Jawa Barat. Tanah latosol mengandung liat lebih dari $60 \%$. Tanah jenis ini sesuai untuk tanaman padi, palawija, lada, coklat, kopi, sayuran, buah-buahan dan ubi. Jenis tanah dominan lainnya yaitu Aluvial, Andosol, Latosol, Brown Forest, Litosol, Grumosol, Mediteran, Organosol, Glei, Podsol Merah Kuning dan Regosol.

\subsection{Kondisi Iklim Wilayah Kajian}

Wilayah Jawa Barat beriklim tropis dengan rata-rata suhu udara $25.5-27.9^{\circ} \mathrm{C}$ dan rata-rata curah hujan bulanan 36-461 mm dengan tipe hujan monsunal (Aldrian \& Susanto, 2003; Hermawan, 2010). Musim hujan Jawa Barat mencapai puncak pada bulan Oktober-April dengan rata-rata nilai curah hujan $315 \mathrm{~mm} /$ bulan dan musim kemarau pada Mei hingga September dengan nilai curah hujan ratarata $97 \mathrm{~mm}$. Hujan tipe ini memiliki perbedaan musim hujan dan kemarau yang jelas. Pola hujan dan suhu udara wilayah Jawa Barat dari data CRU dapat divisualisasikan pada Gambar 3 dan Gambar 4.

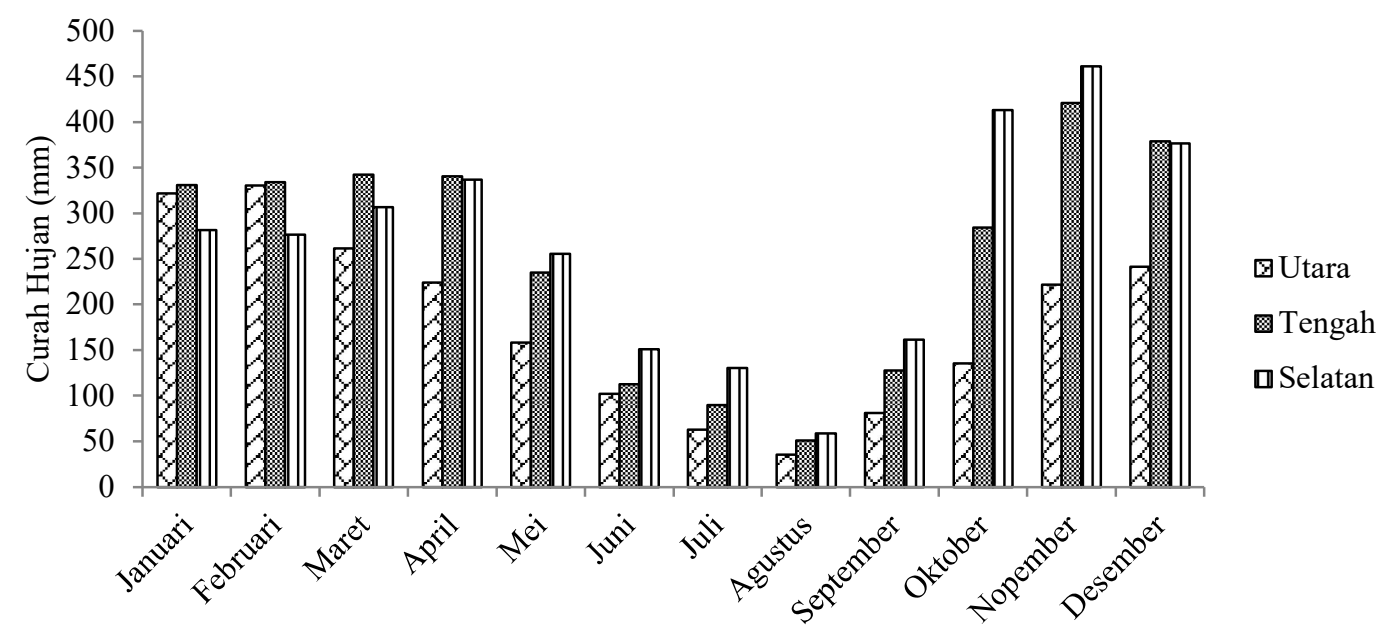

Gambar 3. Curah hujan bulanan Wilayah Jawa Barat tahun 2000-2012

Gambar 3 menunjukkan bahwa wilayah selatan umumnya lebih basah dibandingkan bagian utara Jawa Barat. Curah hujan Jawa Barat Selatan memiliki nilai rata-rata $268 \mathrm{~mm} /$ bulan, sedangkan wilayah bagian Utara hanya $182 \mathrm{~mm} /$ bulan. Pada bulan Januari-April, curah hujan tertinggi terpusat di wilayah bagian tengah dengan nilai rata-rata $337 \mathrm{~mm} /$ bulan, namun pada bulan berikutnya curah 
hujan tertinggi berada di bagian selatan wilayah Jawa Barat. Terjadi penjalaran curah hujan antara bagian utara, tengah dan selatan Jawa Barat. Curah hujan tertinggi di wilayah utara terjadi pada bulan Februari $(331 \mathrm{~mm})$ sedangkan di bagian tengah dan selatan terjadi pada bulan November dengan tinggi hujan 421 dan $461 \mathrm{~mm}$. Hasil ini juga sejalan dengan penelitian Hendrawan et al. (2019) yang menyatakan bahwa curah hujan bulan November dipengaruhi persitiwa ENSO positif dan negatif. Wilayah selatan lebih basah dengan jumlah curah hujan $12 \%$ lebih banyak dari wilayah utara. Wilayah utara memiliki curah hujan terendah paling kecil diantara wilayah lainnya yaitu $36 \mathrm{~mm}$.

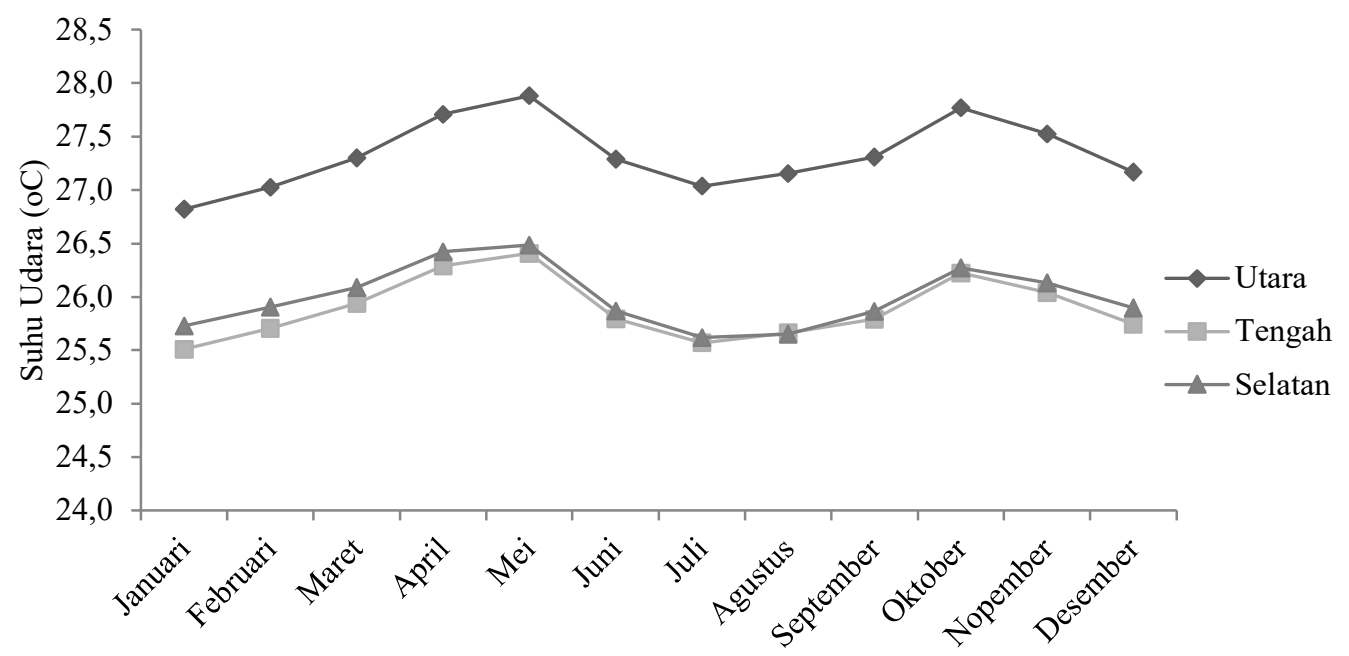

Gambar 4. Suhu udara rata-rata Wilayah Jawa Barat tahun 2000-2012

Suhu udara semua wilayah memiliki pola yang sama (Gambar 4) dengan nilai tertinggi pada bulan Mei dan Oktober dan terendah pada bulan Juli. Wilayah bagian utara memiliki suhu rataan $27.3{ }^{\circ} \mathrm{C}$ (1.3 derajat lebih tinggi) dari wilayah lainnya yang hanya $26{ }^{\circ} \mathrm{C}$. Secara keseluruhan Jawa Barat bagian utara memiliki rataan curah hujan terendah dan suhu tertinggi. Wilayah ini berada di dekat pantai yang memiliki topografi landai dengan dominasi tutupan lahan berupa lahan terbangun serta sawah. Kondisi ini menyebabkan rendahnya kemampuan tanah dalam menyimpan air.

Variabilitas iklim berupa El Niño dan La Niña akan berpengaruh pada pola hujan monsunal. Curah hujan Indonesia berkaitan dengan dengan Niño3.4 dalam kisaran korelasi negatif. Peningkatan suhu muka laut pada Niño3,4 menyebabkan penurunan curah hujan 3 bulanan. Penelitian yang dilakukan oleh Yu et al., (2017) serta Jiang dan Li (2017) menyebutkan bahwa mekanisme fisik yang dapat diusulkan untuk menunda efek ini adalah perubahan sirkulasi Walker sepanjang ekuator Pasifik. Perubahan curah hujan pada tahun normal, El Niño dan La Niña disajikan pada Gambar 5.

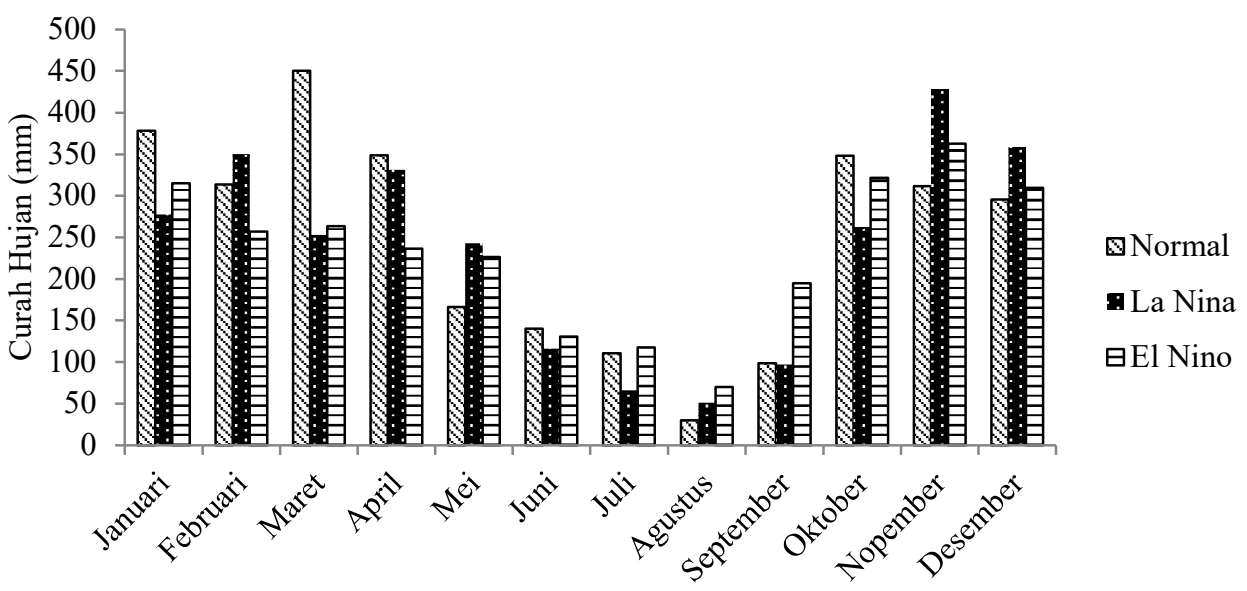

Gambar 5. Pola curah hujan Jawa Barat pada kondisi normal, La Niña dan El Niño 
Berdasarkan Gambar 5 dapat diketahui bahwa selang curah hujan bulanan untuk tahun normal adalah 50-450 mm, 51-tahun La Niña $428 \mathrm{~mm}$ sementara itu pada tahun El Niño adalah dan 70-363 $\mathrm{mm}$. Jumlah curah tahun El Niño $186 \mathrm{~mm}$ lebih rendah dari kondisi normal. Kondisi El Nino tidak berpengaruh signifikan pada musim kemarau (bulan Juni-Juli- Agustus) dan peralihan menuju hujan (bulan September). El Nino terlihat berpengaruh dengan penurunan curah hujan dari kondisi normal pada musim hujan (Desember-Januari-Februari) dan peralihan menuju musim kemarau (MaretApril). Kondisi El Nino terlihat berpengaruh terhadap jumlah curah hujan tahunan. Rata-rata curah hujan tahunan pada kondisi El Niño adalah $2806 \mathrm{~mm}$ normal, sedangkan pada kondisi La Niña dan normal secara berurutan adalah 2991 dan $2833 \mathrm{~mm}$.

\subsection{Kapasitas Air Tersedia}

Nilai kapasitas air tersedia menggambarkan kemampuan tanah dalam mempertahankan air yang dapat dimanfaatkan oleh tanaman. Nilai KAT dipengaruhi oleh dua faktor utama yaitu tutupan lahan dan jenis tanah. Kapasitas air tersedia dikuantifikasi dari dua lapisan tanah: 1) lapisan tanah atas (kedalaman $\pm 25 \mathrm{~cm}$ ) dan lapisan tanah bagian bawah dengan kedalaman sesuai jenis tutupan lahan di atasnya. Tabel penduga KAT Thornthwaite dan Mather (1957) digunakan untuk memudahkan penentuan nilai KAT.

Hasil analisis terhadap tutupan lahan dan jenis tanah, dapat diketahui bahwa rata-rata KAT pada lapisan atas wilayah Jawa Barat adalah $59 \mathrm{~mm}$ dengan selang kisaran 40-73 mm, sedangkan nilai KAT bagian bawah berkisar 59-235 mm dengan rata-rata $162 \mathrm{~mm}$.Nilai KAT bagian utara, tengah dan selatan wilayah Jawa Barat memiliki karakter yang berbeda sesuai dengan tutupan lahan dominan, jenis tanah maupun topografi tanah. Wilayah bagian utara dengan dominasi penggunaan lahan berupa sawah dan lahan terbangun memiliki nilai KAT 41-65 mm (lapisan atas) dan 59-172 $\mathrm{mm}$ (lapisan bawah). Nilai ini lebih rendah dibandingkan wilayah bagian tengah yang memiliki dominasi lahan berupa lahan pertanian (sawah dan kebun) juga hutan. Nilai KAT wilayah ini adalah 52-73 mm pada lapisan atas dan 123-225 mm pada lapisan bawah. Kemampuan tanah dalam menyimpan air paling tinggi berada pada wilayah Selatan dan Barat Jawa Barat. Hal ini ditunjukkan dengan nilai KAT yang mencapai 60-70 pada lapisan atas dan 157-235 pada lapisan bawah. Tutupan lahan pada wilayah ini didominasi oleh kebun dan hutan. Berdasarkan hasil ini dapat dinyatakan bahwa tutupan lahan dengan vegetasi berakar dalam, memiliki KAT yang lebih tinggi. Perbedaan signifikan terlihat pada lapisan tanah bagian bawah.

\subsection{Indeks Kekeringan Palmer}

Indeks kekeringan Palmer memiliki kisaran angka 4 untuk ekstrim basah dan -4 untuk ekstrim kering. Hasil perhitungan menunjukkan bahwa indeks kekeringan di Jawa Barat memiliki selang kriteria yang lebar yaitu dari sangat basah hingga sangat kering. Hal ini berkaitan dengan kondisi curah hujan Jawa Barat yang memiliki pola monsunal. Selain itu, curah hujan mengalami penurunan serta terjadi perubahan awal musim hujan saat terjadi ENSO. Fenomena ENSO berkaitan dengan indeks osilasi selatan yang terjadi di Samudera Pasifik. Tingkat Kejadian El Niño dan La Niña dapat diklasifikan menjadi tiga skala yaitu lemah, sedang dan tinggi. Perbedaan intensitas tesebut dipengaruhi oleh nilai suhu permukaan laut di Samudera Pasifik dan nilai perubahan tekanan udara yang dapat terbaca melalui nilai indeks osilasi selatan yang menyatakan semakin semakin besar nilai negatifnya maka intensitas El Niño akan semakin kuat. Selama periode antara tahun 2000-2012 telah terjadi beberapa El Niño dan La Niña dalam tiga skala tersebut seperti pada Tabel 3. Gambar 6 menunjukkan sebaran indeks kekeringan pada tahun-tahun Normal dan El Niño.

Sebagian besar wilayah bagian utara, barat serta sedikit bagian selatan wilayah Jawa Barat mangalami kekeringan. Kekeringan terparah terjadi di Kabupaten Bekasi, Depok dan Bogor. Pada kondisi El Niño, luasan area sangat basah berkurang 62\%. Kondisi El Niño hanya mengurangi tingkat kebasahan dan tidak menambah luasan kejadian kekeringan ekstrim. Wilayah yang masih mengalami ekstrim basah selama El Niño hanya Kabupaten Majalengka, Cirebon dan Kuningan.

Indeks kekeringan Palmer dikuantifikasi per bulan pada semua tahun data. Nilai indeks berbeda baik secara temporal (tahun normal, El Niño dan La Niña ) maupun secara spasial. Pada saat terjadi El Nino, indeks negatif terjadi berturut-turut hingga 6 bulan. Indeks kekeringan dianalisis setiap tiga bulan berdasarkan musim yaitu: 1) musim penghujan Desember-Januari-Februari (DJF); 2) peralihan 
musim hujan menuju kemarau Maret-April-Mei (MAM); 3) musim kemarau Juni-Juli-Agustus (JJA) dan 4) musim kemarau menuju penghujan September-Oktober-November (SON). Pengelompokan ini bertujuan untuk memudahkan penerapan di bidang pertanian khususnya menentukan masa tanam yang tepat. Selama periode 2000-2012, terjadi perubahan sebaran indeks kekeringan namun demikian sebagian besar wilayah Jawa Barat masih termasuk kategori basah kecuali pada musim kemarau Juni higga Agustus (JJA).

Tabel 3. Tahun El Niño dan La Niña

\begin{tabular}{lll}
\hline \multicolumn{3}{c}{ El Niño } \\
\hline Lemah & Sedang & Tinggi \\
\hline $2004-2005$ & $2009-2010$ & $2002-2003$ \\
\hline $2006-2007$ & \\
\hline \multicolumn{3}{c}{ La Niña } \\
\hline Lemah & Sedang & Tinggi \\
\hline $2000-2001$ & $2007-2008$ & $2010-2011$ \\
\hline $2005-2006$ & \\
\hline $2008-2009$ & \\
\hline $2011-2012$ & \\
\hline Sumber: Golden Gate Weather Services (2020)
\end{tabular}

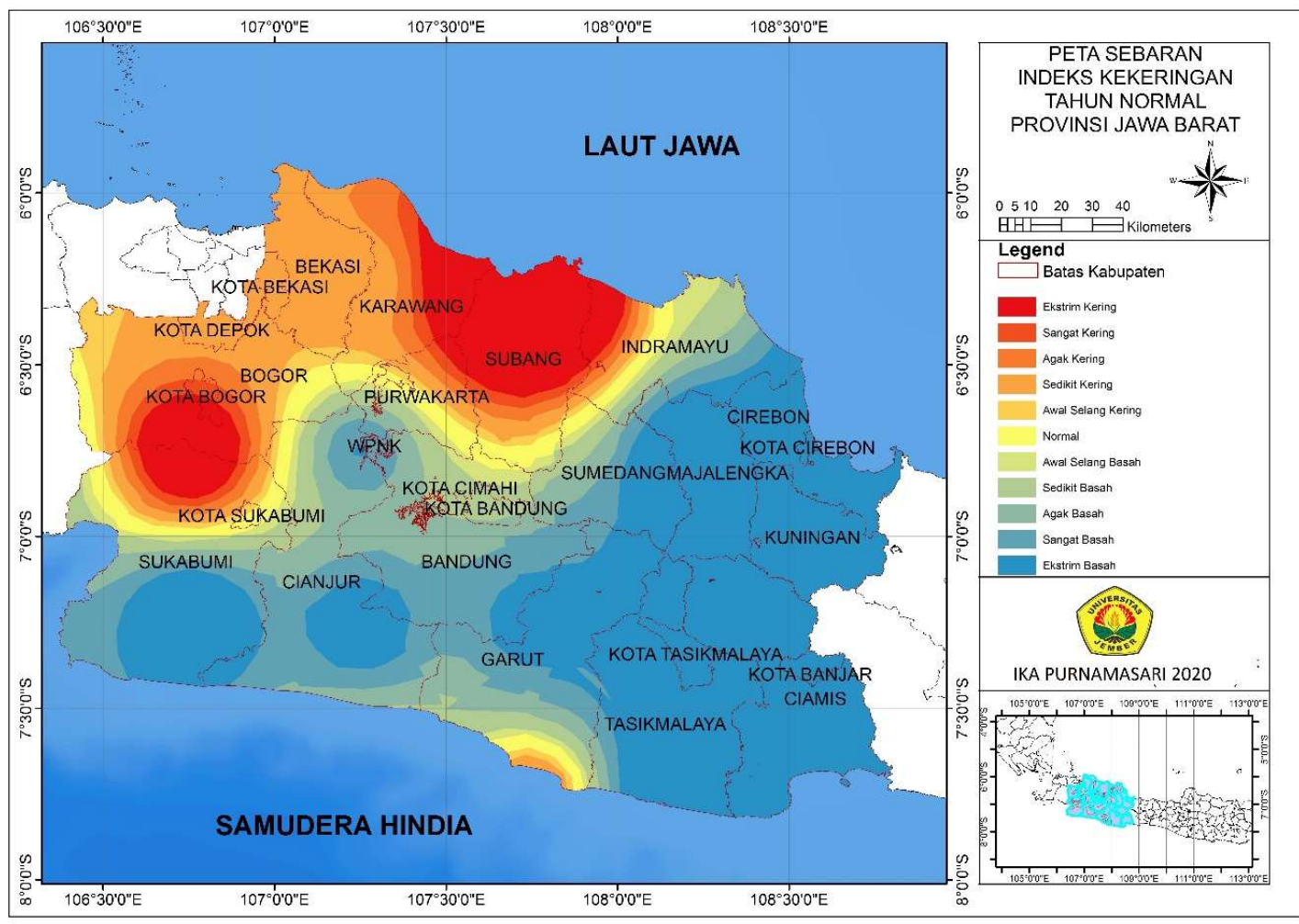

(a) 


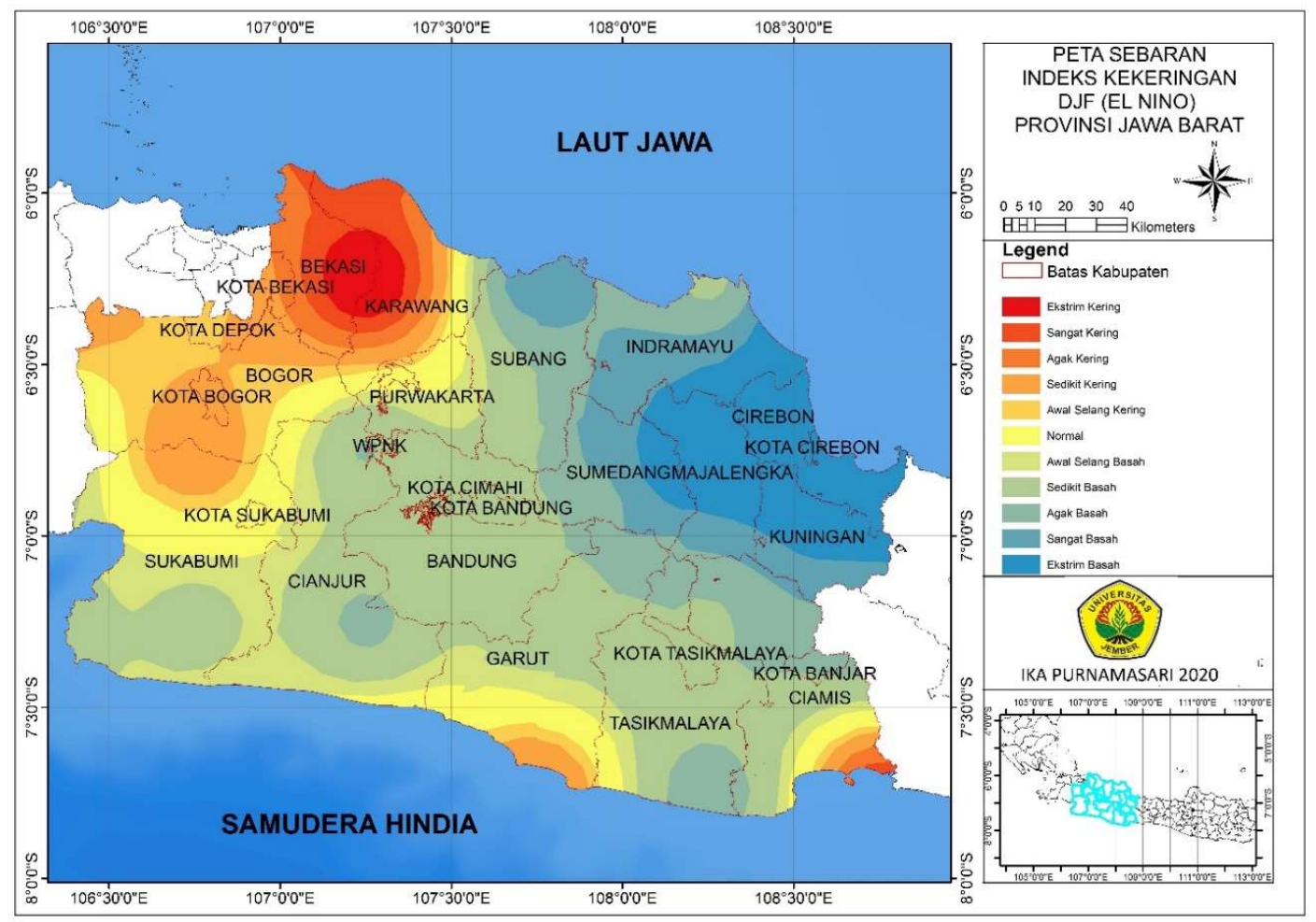

(b)

Gambar 6. Peta sebaran indeks kekeringan tahun Normal (a) dan El Niño (b) di Jawa Barat

Gambar 7 sampai Gambar 10 menampilkan pola spasial rata-rata indeks kekeringan wilayah Jawa Barat berdasarkan kriteria musim. Berdasarkan Gambar dapat diperoleh informasi bahwa pada bulan Desember hingga Februari (DJF), kejadian El Niño tidak memberikan dampak yang berarti terhadap tingkat kekeringan di Jawa Barat. Baik pada kondisi normal maupun El Niño, lebih dari $85 \%$ wilayah masih dalam kondisi basah. Kejadian El Niño hanya menurunkan luas wilayah ekstrim basah sebanyak 2\%. Kekeringan terjadi di bagian selatan dengan pusat indeks terkering di wilayah selatan Bogor, Sukabumi serta Garut dan Ciamis bagian selatan.

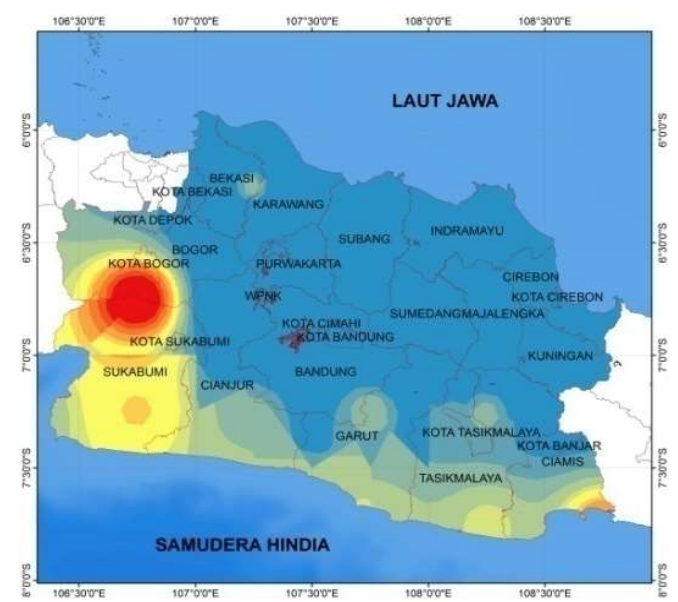

(a)

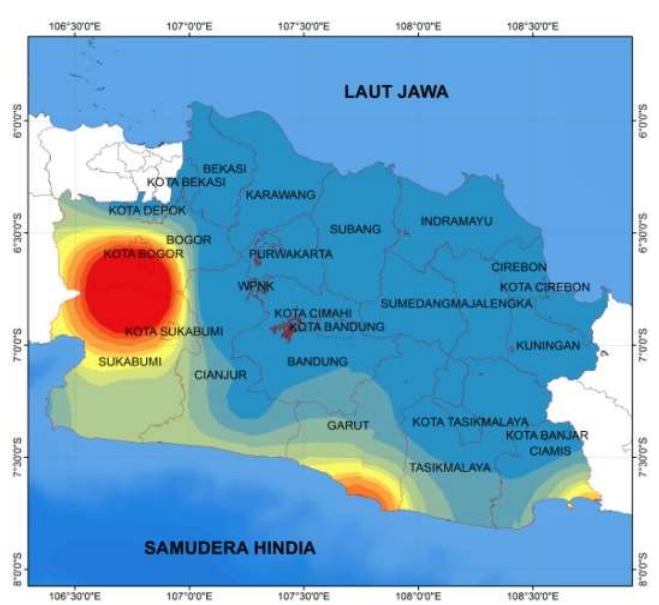

(b)

Gambar 7. Perbandingan sebaran indeks kekeringan tahun El Niño (a) dan Normal (b) di Jawa Barat pada Bulan Desember-Januari-Februari 
Sebagaimana terlihat pada Gambar 8, El Niño mulai memberi sinyal kuat pada bulan Maret hingga Mei (MAM) di wilayah selatan dan barat Jawa Barat. Selama periode El Niño, terjadi peningkatan luas wilayah kering sebanyak $25 \%$ dan penurunan $37 \%$ luas area basah. Penjalaran kekeringan menurun di wilayah utara dan timur Jawa Barat sehingga wilayah paling utara masih pada kondisi ekstrim basah sehingga aktivitas pertanian hendaknya dipusatkan pada wilayah ini. Pada saat El Nino, kondisi ekstrim kering hingga sedikit kering terpusat di Bogor dan selatan Tasikmalaya hingga Garut.

Memasuki musim kemarau (Bulan Juni-Agustus) dan peralihan menuju musim hujan September hingga November, pengaruh El Niño terhadap tingkat kekeringan semakin menguat. Kondisi ini sesuai dengan pernyataan Aldrian (2003) "pengaruh ENSO di Indonesia dimulai pada bulan April dan akan mencapai puncak pada bulan Agustus dan September serta terus menurun sampai bulan November dan Desember". Anomali curah hujan dan suhu permukaan laut (ASPL) Pulau Jawa bernilai negatif sejak musim kemarau (JJA) hingga peralihan (SON) dengan anomali negatif tinggi pada musim peralihan September-November hampir di seluruh wilayah pulau Jawa. Pada periode normal, lebih dari $40 \%$ wilayah dikategorikan kering dengan kekeringan terparah terjadi di wilayah Selatan Garut dan Tasikmalaya.

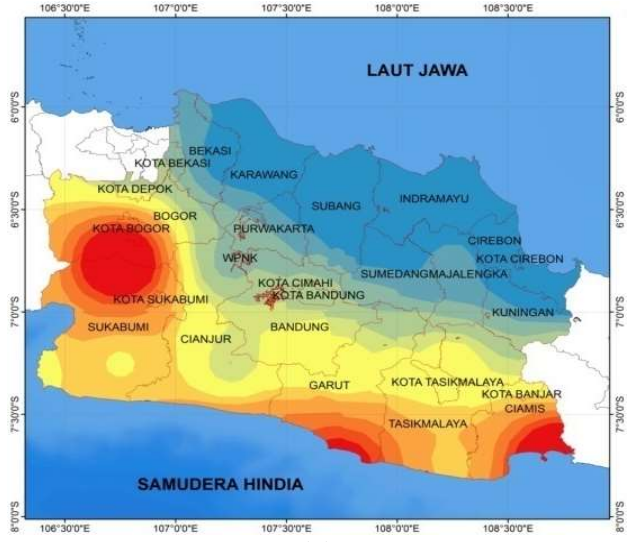

(a)

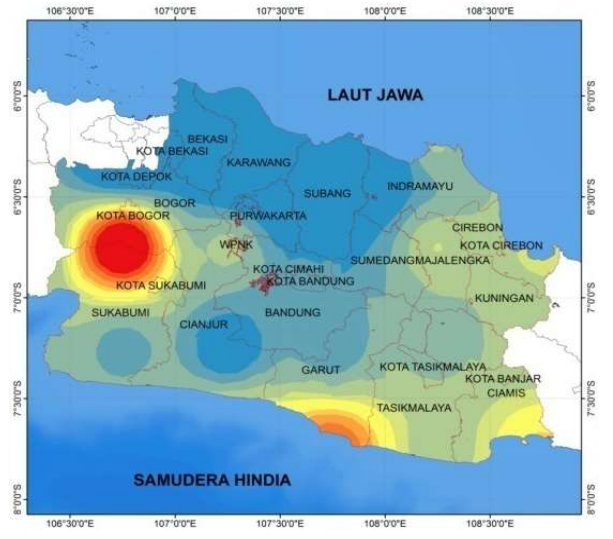

(b)

Gambar 8. Perbandingan sebaran indeks kekeringan tahun El Niño (a) dan Normal (b) di Jawa Barat pada Bulan Maret-April-Mei

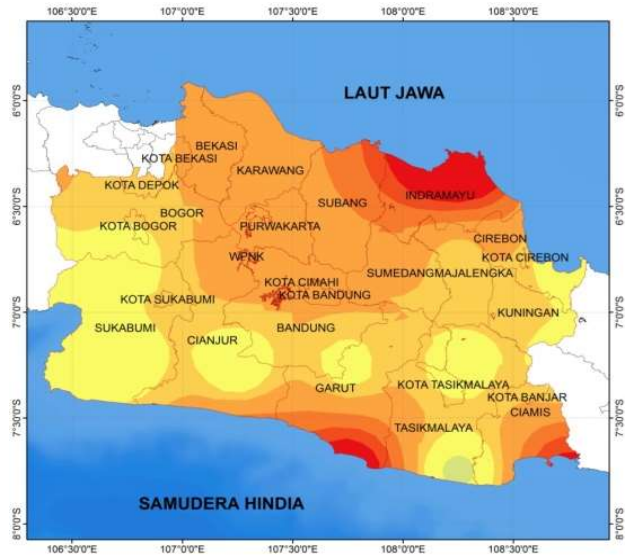

(a)

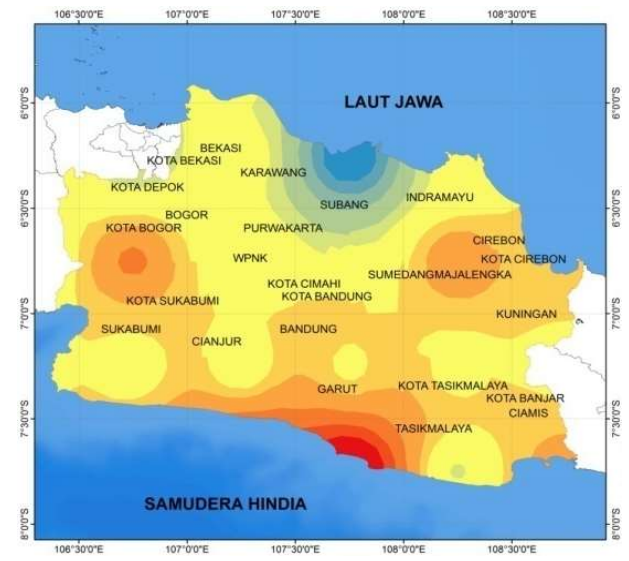

(b)

Gambar 9. Perbandingan sebaran indeks kekeringan tahun El Niño (a) dan Normal (b) di Jawa Barat pada Bulan Juni-Juli-Agustus 


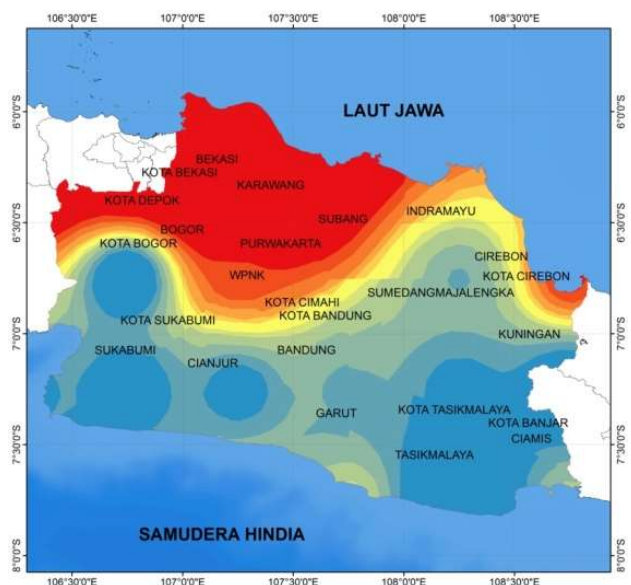

(a)

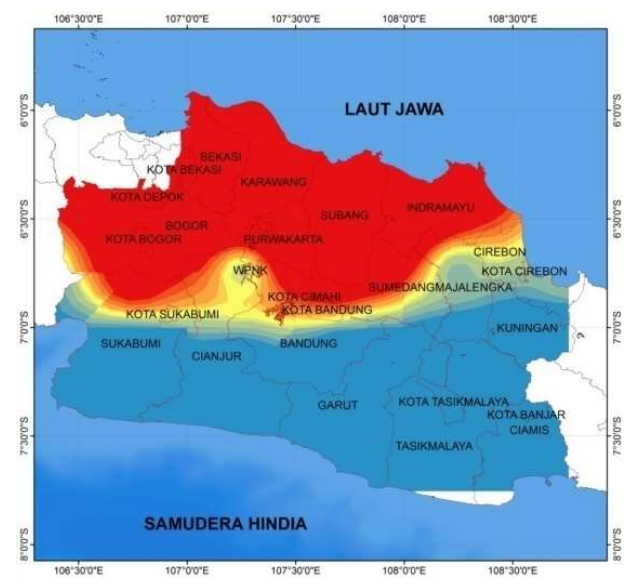

(b)

Gambar 10. Perbandingan sebaran indeks kekeringan tahun El Niño (a) dan Normal (b) di Jawa Barat pada Bulan September-Oktober-November

Kejadian Niño meningkatkan luas wilayah terkena kekeringan menjadi $77 \%$ yaitu meliputi Indramayu (sangat keringa), utara Subang serta selatan Garut dan Tasikmalaya. Pada periode ini aktivitas pertanian tadah hujan tidak dapat dilakukan. Hasil ini sesuai dengan penelitian Setiawan et al (2017) yang menyatakan secara umum keterpaparan kekeringan terparah di Indonesia terjadi selama Juni-Juli-Agustus dan Septermber-Oktober-November, sedangkan pada bulan Maret-AprilMei tidak signifikan terutama pada El Nino lemah dan sedang.

Wilayah Jawa Barat ekstrim basah di bagian selatan dan ekstrim kering di bagian utara pada bulan September hingga November (SON). Hal ini sejalan dengan rilis berita yang dikeluarkan oleh Pemprov Jabar (2017) bahwa wilayah Jawa Barat bagian utara lebih rawan kekeringan. Pada periode bulan September hingga November ini, luas wilayah basah mencapai $50-60 \%$ dan sebagian lainnya dinyatakan kering. Mamenun dan Trinah Wati (2018) menyatakan bahwa terdapat korealasi positif antara lama kekeringan (durasi), tingkat keparahan dan intensitas kekeringan terhadap luas lahan padi sawah yang terkena kekeringan dan gagal panen (puso) pada wilayah Utara Jawa Barat. Pada periode ini, wilayah produsen pangan di utara Jawa Barat mengalami kekeringan ekstrim, sebaliknya bagian tengah dan selatan Jawa Barat memiliki ketersediaan air yang melimpah untuk kegiatan pertanian. Perbedaan yang signifikan antara bagian utara dan selatan Jawa Barat dipengaruhi oleh siklus laut-atmosfer kuat antara wilayah. Tingginya indeks kekeringan di bagian utara pada bulan September-Oktober-November dipengaruhi pula oleh kemampuan tanah dalam menyimpan cadangan air. Wilayah utara dengan tutupan tanah dominan berupa persawahan dan pemukiman memiliki kemampuan menyimpan air yang rendah.

\section{Kesimpulan}

Indeks kekeringan wilayah Jawa Barat memiliki selang yang lebar dari sangat basah hingga sangat kering. Pada Periode Normal, terjadi kekeringan dengan karakter ekstrim kering yang berpusat di Karawang dan Bogor. Sedangkan pada Periode El Nino, karakter agak kering hingga ekstrim kering terpusat di Bekasi dan Karawang. Secara musiman, puncak kekeringan terjadi pada bulan Juni hingga Agustus (JJA) dan September hingga November (SON). Kekeringan merata di seluruh wilayah Jawa Barat Pada periode Juli hingga Agustus serta terpusat di Jawa Barat bagian utara pada bulan September hingga November. Kondisi El Nino meningkatkan karakter kekeringan hingga ekstrim kering dan luasan kekeringan hingga 77\% pada periode musim Juli hingga Agustus. Pada periode Januari hingga Maret kekeringan hanya berpusat di sebagian kecil wilayah barat dan selatan Jawa Barat.

Penelitian ini belum menambahkan data aktual kejadian kekeringan di lapangan. Pada penelitian selanjutnya disarankan untuk menyertakan kejadian kekeringan aktual dalam proses analisis maupun pemetaan pola spasial kekeringan. 


\section{Daftar Pustaka}

Aldrian, E., \& Dwi Susanto, R. (2003). Identification of Three Dominant Rainfall Regions Within Indonesia And Their Relationship to Sea Surface Temperature. International Journal of Climatology, 23(12), 1435-1452.

[BIG] Badan Informasi Geospasial. (2010). Geospasial Untuk Negeri. https:/tanahair.indonesia.go.id/portal-web/inageoportal/\#/ [BPS]Badan Pusat Statistik. 2020. Luas Panen, Produksi dan Produktivitas Padi Menurut Provinsi 2018-2019. Jakarta Pusat : Badan Pusat Statistik. Diakses pada 1 Maret 2020.

Golden Gate Weather Services. 2020. El Niño and La Niña Years and Intensities. https://ggweather.com/enso/oni.htm. Diakses tanggal 24 Agustus 2020.

Guttman, N. B., Wallis, J. R., \& Hosking, J. R. M. (1992). Spatial Comparability of the Palmer Drought Severity Index. JAWRA Journal of the American Water Resources Association, 28(6), 1111-1119.

Haefele, S. M., Kato, Y., \& Singh, S. (2016). Climate ready rice: Augmenting Drought Tolerance With Best Management Practices. Field Crops Research, 190, 60-69.

Harris, Ian, Timothy J Osborn, Phil Jones dan David Lister.(2020). Version 4 of the CRU TS montly high resolution gridded multivariate climate dataset. Scientific Data. www.nature.com/scientificdata/. Diakses pada 1 Maret 2021.

Hendrawan, I. G., Asai, K., Triwahyuni, A., \& Lestari, D. V. (2019). The interanual rainfall variability in Indonesia corresponding to El Niño Southern Oscillation and Indian Ocean Dipole. Acta Oceanologica Sinica, 38(7), 57-66.

Hermawan, E. (2010). Pengelompokkan Pola Curah Hujan Yang Terjadi Di Beberapa Kawasan P. Sumatera Berbasis Hasil Analisis Teknik Spektral. Jurnal Meteorologi Dan Geofisika, 11(2), 75-85.

Jin-Yi Yu1, Xin Wang2, Song Yang3,4, Houk Paek1, and Mengyan Chen2. 2017. The Changing El Niño-Southern Oscillation and Associated Climate Extremes. American Geophysical Union: John Wiley \& Sons, Inc: 2017.

Mavi, H. S., \& Tupper, G. J. (2004). Agrometeorology Principles and Application of Climate Studies in Agriculture. Food Products Press An Imprint of The Haworth Press, Inc. New York.

Mitchell, T. D., \& Jones, P. D. (2005). An improved method of constructing a database of monthly climate observations and associated high-resolution grids. International Journal of Climatology, 25(6), 693-712.

Mulyaqin, Tian. 2020. Pengaruh El Nino dan La Nina terhadap Fluktuasi Produksi Padi di Provinsi Banten. Jurnal Agromet 34(1): 34-41.

Pemprov Jabar. (2017). Wilayah utara Jabar rawan kekeringan. http://jabarprov.go.id/index.php/news/24407/Wilayah_Utara_Jabar_Rawan_Kekeringan.

Qian, J. H., Robertson, A. W., \& Moron, V. (2010). Interactions among ENSO, the Monsoon, and Diurnal Cycle in Rainfall Variability over Java, Indonesia. Journal of the Atmospheric Sciences, 67(11), 3509-3524.

Santoso, A.B., (2016). Pengaruh Perubahan Iklim terhadap Produksi Tanaman Pangan di Provinsi Maluku 29-38.

Setiawan, Amsari Mudzakir, Woo-Seop Leeb and Jinyoung Rhee. (2017). Spatio-temporal characteristics of Indonesian drought related to El Niño events and its predictability using the multi-model ensemble.International Journal of Climatology (2017). 
Surmaini, E. \& Faqih, A. (2016). Kejadian Iklim Ekstrem dan Dampaknya Terhadap Pertanian Tanaman Pangan di Indonesia. Jurnal Sumberdaya Lahan, 10(2): 115-128.

Tallaksen, L. M., Hisdal, H., \& Lanen, H. A. J. V. (2009). Space-Time Modelling Of Catchment Scale Drought Characteristics. Journal of Hydrology, 375(3-4), 363-372.

[USGS] United States Geological Survey. (2021). Thornthwaite Montly Water Balance Model. https://wwwbrr.cr.usgs.gov/projects/SW_MoWS/Thornthwaite.html\#: :text=The\%20Thornth waite $\% 20$ water $\% 20$ balance $\% 20$ (Thornthwaite,are $\% 20$ monthly $\% 20$ temperature $\% 20$ and $\% 20 p$ recipitation. Diakses pada 26 Februari 2021

Wang, S., Mo, X., Hu, S., Liu, S., \& Liu, Z. (2018). Assessment Of Droughts And Wheat Yield Loss On The North China Plain With An Aggregate Drought Index (ADI) Approach. Ecological Indicators, 87(November 2017), 107-116. 